УДК 371.13:378:372.4

DOI https://doi.org/10.32782/apv/2021.2.2

\title{
Оксана БАРТКІВ
}

кандидат педагогічних наук, дочент, доцент кафедри загальної педагогіки та дошкільної освіти, Волинський національний університет імені Лесі Українки, просп. Волі, 13, м. Луцьк, Волинська обл., Україна, 43025

ORCID: 0000-0003-1301-2169

\section{Оксана СМАЛЬКО}

кандидат педагогічних наук, старший викладач, старший викладач кафедри педагогіки, психології та окремих методик, Комунальний заклад вищої освіти «Луиький педагогічний коледж Волинської обласної ради», пр. Волі, 36, м. Луцььк, Волинська обл., 43010

ORCID: 0000 -0003-1145-1897

Бібліографічний опис статті: Бартків, О., Смалько, О. (2021). Професійна підготовка майбутніх учителів до організації виховної роботи: сутність та структура. Acta Paedagogica Volynienses, 2, 10-15, doi: https://doi.org/10.32782/apv/2021.2.2

\section{ПРОФЕСІЙНА ПІДГОТОВКА МАЙБУТНІХ УЧИТЕЛІВ ДО ОРГАНІЗАЦІЇ ВИХОВНОЇ РОБОТИ: СУТНІСТЬ ТА СТРУКТУРА}

У статті подано теоретичний аналіз сутності та структурних компонентів професійної підготовки вчителя до організаиії виховної роботи в закладі освіти. Актуальність проблеми обумовлена виріменням завдань підготовки майбутніх педагогічних праиівників, здатних виховувати громадянина Украйни, патріота, інтелектуально розвинену, духовно і морально зрілу особистість, готову протистояти викликам глобалізаиї житття.

Мета статті полягає в обтрунтуванні сутності та структурних компонентів професійної підготовки вчителя до організаиї виховної роботи зі школярами. Реалізачія передбачала розв'язання завдань: 1) розкрити сутність виховної роботи та підготовки вчителя до організащії виховної роботи; 2) обтрунтувати компоненти професійної підготовки вчителя до організаиї̈ виховної роботи в закладі освіти.

Виховну роботу розглянуто як иілеспрямовану систему виховних справ, які мають на меті формування високо та всебічно-розвиненої особистості з власними цінностями, креативним мисленням, відповідальністю, інтересами й настійними прагненнями щодо їх задоволення.

Професійну підготовку майбутнього вчителя до організації виховної роботи схарактеризовано як иілеспрямований процес оволодіння загальними та фаховими компетентностями організації та проведення виховних справ у закладах освіти. А професійну готовність майбутніх вчителів до організаиії виховної роботи - як сформоване інтегральне ціннісно-особистісне утворення, яке забезпечує професійний розвиток особистості студента через свідоме гармонійне поєднання знань, умінь, навичок, досвіду продуктивної організаиії виховної роботи з учнями, сприяє успішній комунікаиї з суб'єктами виховної роботи та включає здатність до постійного професійного самовиховання, самовдосконалення, самовираження в сфері організащії виховної роботи.

У структурі професійної підготовки вчителів до організаџї виховної роботи з учнями виокремлено мотиваційну,когнітивну, діяльнісну та рефлексивну складові.

Ключові слова: професійна підготовка, вчитель, виховна робота, професійна підготовка вчителя до організації виховної роботи, структура професійна підготовка вчителя до організаиії виховної роботи. 


\section{Oksana BARTKIV}

PhD in Pedagogy, Associate Professor, Senior Lecturer at the Department of General Pedagogy and Preschool Education, Lesya Ukrainka Volyn National University, 13 Voli ave., Lutsk, Volyn region, Ukraine, 43025

ORCID: 0000-0003-1301-2169

\section{Oksana SMALKO}

PhD in Pedagogy, Assistant Professor, Assistant Professor at the Department of Pedagogy, Psychology and Some Methods, The Municipal Higher Educational Institution "Lutsk Pedagogical College" of the Volyn Regional Council, Volya Ave., 36, Lutsk, Volyn region, 43010

ORCID: 0000-0003-1145-1897

To cite this article: Bartkiv, O. \& Smalko, O. (2021). Profesiina pidhotovka maibutnikh uchyteliv do orhanizatsii vykhovnoi roboty: sutnist ta struktura [Professional training of future teachers to the organization of educational work: essence and structure]. Acta Paedagogica Volynienses, 2, 10-15, doi: https://doi.org/10.32782/apv/2021.2.2

\section{PROFESSIONAL TRAINING OF FUTURE TEACHERS TO THE ORGANIZATION OF EDUCATIONAL WORK: ESSENCE AND STRUCTURE}

The article presents a theoretical analysis of the essence and structural components of teacher training for the organization of educational work in an educational institution. The urgency of the problem is due to the problem of training future teachers, able to educate a national of Ukraine, patriot, intellectually developed, spiritually and morally mature person, ready to meet the challenges of globalization of life.

The purpose of the article is the rationale the essence and structural components of teacher training for the organization of educational work in school. Implementation provided solving problems: 1) to reveal the essence of educational work and teacher preparation for the organization of educational work; 2) substantiate the components of teacher training for the organization of educational work in an educational institution.

Educational work is considered as a purposeful system of educational affairs, directed at forming a highly and comprehensively developed personality with formed personal values, creative thinking, responsibility, interests and persistent aspirations for their satisfaction.

Professional training of future teachers to organize educational work characterized as a purposeful process of mastering the general and professional competencies of the organization and conducting educational affairs in educational institutions. Professional readiness of future teachers to organize educational work - as an integrated value-based personal formation, which provides professional development of the student's personality through a conscious harmonious combination of knowledge, skills, abilities, experience of productive organization of educational work with students, promotes successful communication with the subjects of educational work and includes the ability to continuous professional self-education, self-improvement, self-expression in the organization of educational work.

Key words: professional training, teacher, educational work, professional training of a teacher for the organization of educational work, structure professional training of a teacher for the organization of educational work.

Постановка проблеми в загальному вигляді. Соціальна реальність кардинально змінила пріоритети життєвих цінностей, призвела до загального погіршення взаємин між людьми, вплинула на зниження рівня загальнолюдської культури й культури загалом. Модифікація змісту та системи виховання особистості вплинули і на модернізацію в суспільній природі людини, що, в свою чергу, вимагає пошуку оновлених підходів до підготовки майбутніх учителів до виховної роботи зі школярами. Тому перед закладами вищої освіти постає завдання підготовки майбутніх педагогічних працівників, здатних виховувати громадянина України, патріота своєї країни, інтелектуально розвинену, духовно і морально зрілу особистість, готову протистояти викликам глобалізації життя. Вирішення окресленого завдання можливе за умови конструктивно організованої виховної роботи в закладах вищої освіти, продуманого вибору форм, методів ії реалізації.

Про необхідність упровадження принципово нових підходів до організації виховної роботи учнівської молоді наголошується у Законах України «Про освіту», «Про вищу освіту», Національній стратегії розвитку освіти в Україні на період до 2021 року, Концепції нової української школи та ін. Відповідно до «Основних орієнтирів виховання учнів 1-12 класів», сучасний зміст виховання складають науково обгрунтована 
система загальнокультурних і національних цінностей та соціально значимих якостей особистості, що характеризують ії ставлення до суспільства і держави, інших людей, самої себе, праці, природи, мистецтва. Система цінностей і якостей дитини розвивається та виявляється через ii власні ставлення [1]. Заклади освіти мають здійснювати підготовку свідомої національної інтелігенції, сприяти оновленню та збагаченню інтелектуального генофонду нації, що забезпечить високу ефективність діяльності майбутніх спеціалістів. Це повинно бути досягнуто через формування «Я» - концепції людини-творця на основі самоосвіти, саморозвитку, самовиховання, самовдосконалення студентів [2]. Таке трактування сутності проблеми $є$ переконливим свідченням важливості підготовки вчителя до організації виховної роботи з учнями.

Аналіз останніх досліджень і публікацій. Проблеми організації виховної роботи в закладах загальної середньої освіти представлені в працях Л. Болотіної, Т. Дем'янюк, Н. Казакової, С. Карпенчук, Б. Кобзаря, Н. Кудикіної, С. Мартиненко, В. Омеляненко, Г. Тарасенко та ін. Специфіку підготовки майбутніх учителів до організації виховної роботи розкривають С. Барановська, О. Демченко, О. Дубасенюк, Н. Казакова, І. Казанжи, Г. Кіт, С. Лавриненко, С. Литвиненко, Л. Мацук, Б. Нестерович, Г. Пустовіт, Г. Троцко, О. Філіпп’єва, О. Шквир та ін. Аналіз поглядів учених засвідчив неоднозначність у визначенні сутності та структури професійної підготовки вчителя до організації виховної роботи зі школярами.

Мета статті полягає в обгрунтуванні сутності та структурних компонентів професійної підготовки вчителя до організації виховної роботи зі школярами. Реалізація передбачала розв'язання завдань: 1) розкрити сутність виховної роботи та підготовки вчителя до організації виховної роботи; 2) обгрунтувати компоненти професійної підготовки вчителя до організації виховної роботи в закладі освіти.

Виклад основного матеріалу. Розкриваючи сутність професійної підготовки майбутніх учителів до організації виховної роботи, вдамося до аналізу змісту понять «підготовка», «професійна підготовка», «підготовка вчителя до організації виховної роботи».

В Енциклопедії освіти підготовка розглядається як сукупність оволодіння особистістю спеціальними знаннями, уміннями, навичками, необхідними якостями, надбанням трудового досвіду і норм поведінки, які забезпечують можливість успішної праці за обраною професією [3, с. 390]. У Великому тлумачному словнику сучасної української мови термін «підготовка/підготувати» аналізується, як давати необхідний запас знань, передавати навички, досвід і т. ін. в процесі навчання, практичної діяльності [4, с. 767]. Екстраполюючи це визначення на професійну діяльність, приходимо до висновку, що професійна підготовка - це процес оволодіння системою знань, умінь і навичок, досвіду діяльності та розвиток професійно важливих якостей, необхідних для успішної професійної діяльності.

По-іншому до трактування професійної підготовки підходить Р. Вайнола, визначаючи іiі як сукупність соціального, професійного та особистісно-морального розвитку майбутнього фахівця у сприятливих умовах технологічного та науково-методичного середовища закладу вищої освіти [5, с. 17]. У контексті нашого дослідження, заслуговує уваги визначення запропоноване О. Абдуліною, яка наголошує, що професійна підготовка - це, перш за все, система, що поєднує відносно самостійні, але взаємозалежні системи підготовки, до яких входять спеціальнонаукова, психолого-педагогічна й загальнокультурна підготовка. Учена переконливо доводить, що професійна підготовка студентів педагогічних спеціальностей має здійснюватися в єдності фахової та загальної підготовки, які у підсумку забезпечують належний рівень оволодіння майбутнім вчителем важливими складовими педагогічної професії [6, с. 24].

На єдності загальної й фахової підготовки майбутнього вчителя акцентує увагу й Л. Гусак, визначаючи підготовку як процес набуття соціального досвіду через засвоєння певної навчальної інформації, що приводить до формування готовності як сукупності певних компетенцій. На основі аналізу поглядів учених (О. Лугова, Т. Осадча, О. Павлик, В. Семиченко та ін.) учена під професійною підготовкою фахівця розуміє процес здобуття професійної освіти 3 окремого напряму його підготовки, у результаті якого формуються загальнопрофесійні й фахові компетентності [7, с. 13 ].

До нашого дослідження адаптуємо визначення, запропоноване Л. Гусак [7], відповідно 
до якого професійна підготовка майбутніх учителів - це процес набуття ними соціального досвіду через засвоєння й оволодіння педагогічними компетентностями організації освітнього процесу в закладах освіти.

Результатом професійної підготовки є готовність фахівця виконувати професійні функції. Під готовністю до педагогічної діяльності вчені (Р. Вайнола, Л. Гусак, А. Денисенко та ін.) розглядають складне особистісне утворення, що забезпечує високі результати педагогічної роботи та інтегрує в собі професійно-моральні погляди та переконання, професійну спрямованість психічних процесів, професійні знання, уміння, навички, а також спрямованість на педагогічну працю, здатність до подолання труднощів, самооцінки результатів такої праці, потребу в постійному професійному самовдосконаленні $[7 ; 9 ; 10]$.

У контексті нашого дослідження резюмуємо, що в майбутнього вчителя має бути сформована готовність організовувати виховну роботу в закладах освіти. Виховна робота як важливий компонент виховного процесу спрямований на формування особистості, розвиток іiі потенційних можливостей, креативності, здатності до самовдосконалення шляхом ефективної організації освітньої діяльності учнів, їх вільного часу, задоволення навчально-пізнавальних, пошуково-дослідницьких і культурних потреб. Обов'язковою вимогою успішності цього процесу є скоординована взаємодія всіх суб'єктів.

Виховання учнів здійснюється як в процесі навчання, так і в позанавчальний час, тобто у процесі виховання, який, за визначенням М. Фіцули, розглядається як система заходів, спрямованих на формування всебічно й гармонійно розвиненої особистості [8, с. 232], а за трактуванням Н. Волкової, як процес виховання, який окрім використання різноманітних методів, прийомів, засобів виховання, передбачає постійне виявлення результатів виховних впливів, корекції змісту й методики виховної роботи [9].

Отже, аналіз психолого-педагогічної літератури $[2 ; 7 ; 8 ; 10]$ засвідчує, що виховна робота вченими трактується як: система виховних заходів, яка є обов'язковим компонентом освітнього процесу і реалізується задля створення умов для професійного, інтелектуального та морально-духовного становлення студентів, їхньої самореалізації; цілеспрямована діяль- ність, орієнтована на створення позитивно виховного середовища та організацію спільної життєдіяльності вихователів і вихованців, спрямовану на формування ціннісних орієнтацій, творчий розвиток особистості .

Нами на основі аналізу поглядів учених та врахування власного досвіду виховної роботи зі студентами, виховну роботу нами розглянуто як цілеспрямовану систему виховних справ, які мають на меті формування високо та всебічнорозвиненої особистості з власними цінностями, креативним мисленням, відповідальністю, інтересами й настійними прагненнями щодо їх задоволення.

Оскільки, виховна робота спрямована на формування в учнів національного світогляду, засвоєння ними системи цінностей (вселюдських, національних, громадянських, родинних, особистого життя); розвиток творчих та інтелектуальних здібностей; залучення школярів до просвітницької, спортивної, профілактичної та інших видів діяльності, різноплановій діяльності за інтересами; формування лідерських якостей тощо, то вчитель має володіти компетенціями організовувати ці види діяльності дитини.

Узагальнюючи погляди вчених на трактування понять «професійна підготовка», «професійна готовність», «виховна робота», професійну підготовку майбутнього вчителя до організації виховної роботи розглядаємо як цілеспрямований процес оволодіння загальними та фаховими компетентностями організації та проведення виховних справ у закладах освіти. А професійну готовність майбутніх вчителів до організації виховної роботи визначаємо як сформоване інтегральне ціннісно-особистісне утворення, яке забезпечує професійний розвиток особистості студента через свідоме гармонійне поєднання знань, умінь, навичок, досвіду продуктивної організації виховної роботи з учнями, сприяє успішній комунікації 3 суб'єктами виховної роботи та включає здатність до постійного професійного самовиховання, самовдосконалення, самовираження.

Трансформуючи ідеї А. Денисенко [10] щодо структури виховної роботи можемо стверджувати, що організація виховної роботи передбачає наявність таких складових компонентів: мети (цілевизначення); завдань, змісту, методів, засобів, форм, принципів, які взаємозв'язані між собою і взаємозумовлені; суб'єктів 
iз різними типами відносин між ними; середовища, створеного суб'єктами; управління, що забезпечує інтеграцію всіх компонентів організації виховної роботи в єдину цілісність. Зазначаємо, що кожен з вказаних компонентів взаємозалежний та взаємообумовлений іншими компонентами. Лише цілісність і послідовність їх реалізації забезпечить ефективність процесу виховання.

Важливим у контексті нашого дослідження $\epsilon$ визначення структури підготовки майбутніх учителів до організації виховної роботи 3 учнями. Аналіз психолого-педагогічної літератури засвідчив, що більшістю вчених $[2 ; 4 ; 6 ; 10]$ виокремлюються такі структурні компоненти підготовки педагога до виховної роботи: мотиваційний, виконавський, теоретичний та практичний; перетворюючий, пізнавальний, ціннісний та комунікативний; орієнтаційний, пізнавально-операційний, емоційно-вольовий, психофізіологічний; педагогічний, змістовий та технологічний та ін.

Узагальнюючи погляди науковців до структури професійної підготовки вчителя до організації виховної роботи з учнями, виокремимо такі ії складові:

1) мотиваційну, що передбачає мобілізацію суб'єктних зусиль майбутнього вчителя до необхідності оволодіння компетентностями організації виховної роботи в школі. У зв'язку 3 тим, що педагогічна діяльність $є$ полівмотивованою, іiі мотиви поділяються на специфічно-пізнавальні (прагнення пізнати нове, невідоме) та неспецифічні (обумовлені зовнішніми обставинами, діями). У свою чергу, специфічно-пізнавальні мотиви характеризуються як пізнавальні потреби, викликані конкретними умовами, задачами діяльності та спілкування і відповідно є стійкими;

2) когнітивну - володіння знаннями змісту виховної роботи та іiі організації школярами i репрезентований системою знань про мету, сутність виховної роботи, іiі зміст, стратегії і прийоми організації;

3) діяльнісну - прояв сформованості умінь організовувати виховну роботу у різноманітних стандартних і нестандартних ситуаціях;

4) рефлексивну - емоційно-вольова рефлексія, здатність аналізувати результати проведеної виховної роботи, визначати прогалини в ній та проектувати зміст виховної роботи на майбутне.

Висновки та перспективи подальших розвідок напряму. Отже, процес професійної підготовки майбутніх учителів має передбачати цілеспрямованість і систематичність формування в них готовності організовувати виховну роботу в закладах освіти.

Результати проведеного аналізу дозволили професійну підготовку майбутнього вчителя до організації виховної роботи розглядати як цілеспрямований процес оволодіння загальними та фаховими компетентностями організації та проведення виховних справ у закладах освіти, а їхню професійну готовність - як сформоване інтегральне ціннісно-особистісне утворення, що забезпечує професійний розвиток студента через свідоме гармонійне поєднання знань, умінь, навичок, досвіду продуктивної організації виховної роботи з учнями, сприяє успішній комунікації з суб'єктами виховної роботи та включає здатність до постійного професійного самовиховання, самовдосконалення, самовираження. У структурі професійної підготовки вчителів до організації виховної роботи 3 учнями виокремлено мотиваційну,когнітивну, діяльнісну та рефлексивну складові.

Проведене дослідження не претендує на вичерпний розгляд проблеми, подальшого дослідження потребують питання визначення актуального стану готовності майбутніх учителів до організації виховної роботи в закладах освіти.

\section{ЛІТЕРАТУРА:}

1. Основні орієнтири виховання учнів 1-12 класів. URL: http://old.mon.gov.ua/images/files/pozashkilna/1243.doc.

2. Твердохліб Т.С. Педагогічна майстерність класного керівника в організації виховної роботи : навч.-метод. посіб. Харків : ХНПУ ім. Г.С. Сковороди, 2017. 154 с.

3. Енциклопедія освіти / Академія пед. наук України; головний редактор В.Г. Кремінь. Київ : Юрінком Інтер, 2008. $1040 \mathrm{c}$.

4. Великий тлумачний словник сучасної української мови / уклад. і голов. ред. В.Т. Бусел. Київ ; Ірпінь : ВТФ «Перун», 2004. 1728 с.

5. Вайнола Р.Х. Педагогічні засади особистісного розвитку майбутнього соціального педагога в процесі професійної підготовки : автореф. дис. на здобуття наук. ступеня д-ра. пед. наук : спец. 13.00.04. Київ, 2009. 46 с. 
6. Абдуллина О.А. Общепедагогическая подготовка учителя в системе высшего образования. Москва : «Просвещение», 1990. $141 \mathrm{c}$.

7. Гусак Л.Є. Теоретичні і методичні основи підготовки майбутніх учителів до асоціативного навчання іноземних мов учнів початкової школи: дис. докт. пед. наук : спец. 13.00.04. Київ, 2014. 43c.

8. Фіцула М.М. Педагогіка вищої школи : навч. посіб. Київ : Академвидав, 2006. 352 с.

9. Волкова Н.В. Педагогіка : посібник для студентів вищих навчальних закладів. Київ : Академія, 2002.576 с.

10. Денисенко А.О. Організація моніторингу виховної системи вищих педагогічних навчальних закладів : дис. ... канд. пед. наук : спец. 13.00.01. Харків, 2008. 220 с.

\section{REFERENCES:}

1. Osnovni oriientyry vykhovannia uchniv 1-12 klasiv [Basic guidelines for educating students in grades 1-12] (2017). old.mon.gov.ua Retrieved from: http://old.mon.gov.ua/images/files/pozashkilna/1243.doc [in Ukrainian].

2. Tverdokhlib, T.S. (2017) Pedahohichna maisternist klasnoho kerivnyka v orhanizatsii vykhovnoi roboty [Pedagogical skill of the class teacher in the organization of educational work]. Kharkiv: KhNPU im. H.S. Skovorody. 154 p. [in Ukrainian].

3. Entsyklopediia osvity [Encyclopedia of Education] (2008) Akademiia ped. nauk Ukrainy; V.H. Kremin. (Ed.) Kyiv: Yurinkom Inter. 1040 p. [in Ukrainian].

4. Velykyi tlumachnyi slovnyk suchasnoi ukrainskoi movy [Large explanatory dictionary of the modern Ukrainian language] (2004) V.T. Busel (Ed.). Kyiv; Irpin: VTF "Perun". 1728 p. [in Ukrainian].

5. Vainola, R.Kh. (2009) Pedahohichni zasady osobystisnoho rozvytku maibutnoho sotsialnoho pedahoha v protsesi profesiinoi pidhotovky [Pedagogic basics for personality development in professional training of future social pedagogue]. Extended abstract of candidate's thesis. Kyiv. 46 p. [in Ukrainian].

6. Abdullyna, O.A. (1990) Obshchepedahohycheskaia podhotovka uchytelia $v$ systeme vyssheho obrazovanyia [General pedagogical training of teachers in the system of higher education]. Moscow: "Prosveshchenye". 141p. [in Russian].

7. Husak, L.Ye. (2014) Teoretychni i metodychni osnovy pidhotovky maibutnikh uchyteliv do asotsiatyvnoho navchannia inozemnykh mov uchniv pochatkovoi shkoly [Theoretical and methodological basis of training future teachers for the associative teaching the foreign languages to primary school pupils.]: Candidate's thesis. Kyiv. 43s. [in Ukrainian].

8. Fitsula, M.M. (2006) Pedahohika vyshchoi shkoly [Pedagogy of high school]. Kyiv: Akademvydav, 2006. 352 p. [in Ukrainian].

9. Volkova, N.V. (2002) Pedahohika [Pedagogy]: posibnyk dlia studentiv vyshchykh navchalnykh zakladiv. Kyiv: Akademiia. 576 p. [in Ukrainian].

10. Denysenko A.O. (2008) Orhanizatsiia monitorynhu vykhovnoi systemy vyshchykh pedahohichnykh navchalnykh zakladiv [Organization of monitoring of the educational system of higher pedagogical educational institutions]. Candidate's thesis. Kharkiv. 220 p. [in Ukrainian]. 